\title{
Ethnomathematics in Traditional Wayang Performance in Surakarta as a Source of Mathematics Learning in Junior High School
}

\author{
Della Narulita $^{1}$, M Mardiyana ${ }^{2}$, D R S Saputro ${ }^{2}$ \\ ${ }^{1}$ Master Student in Postgraduate of Mathematics Education of Sebelas Maret University, Surakarta, Indonesia \\ ${ }^{2}$ Mathematics Education of Sebelas Maret University, Surakarta, Indonesia \\ dellanarulita31@gmail.com
}

\begin{abstract}
Mathematics is used in all aspects of life and emphasizes the activities of reasoning. Mathematics had related to our daily activities and can identify the cultural point of view. Ethnomathematics include mathematical ideas develop by cultures. The aim of this research is ethnomathematics practiced by the community especially in traditional wayang art in Surakarta that can be used as a source of learning mathematics in junior high school. This research used descriptive qualitative research whichdata collection techniques by observation, interviews, and documentation. Data validity used triangulation. The research procedure includes several stages, namely data collection, data selection, data analysis, drawing conclusions, and preparation of research reports. The result of the research showed that traditional wayang art performance in Surakarta contained ethnomathematics can be used as a source of learning mathematics in junior high school such as 1) modulo 9, 2) geometry of space, 3) even odd number, 4) rectangle, and 5) circle.
\end{abstract}

Keywords : ethnomathematics; traditional wayang; performance; mathematics learning; Surakarta

\section{Introduction}

Mathematics is the study of knowledge that examines about the patterns of organized order or structure so that it is closely related to undefined elements into defined elements and axiom proof. Because it deals with abstract concepts that are hierarchical, mathematics emphasizes on rational and reasoning activities. Therefore, mathematics is in fact closely related to daily life.

One of mathematics study that is closely related to daily life is the study of mathematics in culture. Similarly, Ambrosio (1985)assertion that mathematical practice can be identified from cultural groups and it can be regarded as mathematical learning found in any culture. Torres-VelasquezD andLobo (2004)also states that culture provides teaching about mathematics by connecting mathematics with culture and experience. One of the branches of science that connect education and culture is ethnomathematics. It includes mathematical ideas, thoughts, and practices which developed by all cultures (Barton, 1996). In line with Gerdes (1994) states that ethnomathematics is a mathematics applied by a particular culture group. Orey(2011) supports this idea by stating that ethnomathematics is when concepts are connected to experience of culture and daily life - students' daily life, so it improves their ability in deepening their understanding and skills of mathematics. Ethnomathematics is a mathematics learning that is studied in the culture. Culture understanding is defined as very narrow, that is custom and art that fulfills aesthetics values. Culture understanding is essentially wider than the custom and art. Koentjaraningrat(1985: 5) states that the scope of cultural content and components includes religious systems and religious ceremonies, community systems and organization, knowledge systems, languages, arts, living systems, and technology and equipment systems. 
Indonesia has various cultures. One of city that has a distinctive culture is Surakarta. Surakarta has many cultures starting from the palace, art of wayang, batik, traditional market and gamelan. An interesting culture studied is the traditional art of wayang in Surakarta. Traditional art of wayang is traditional performing art that generally tell the story of Mahabarata and Ramayana played by humans with the stages and the accompaniment of traditional and typical music. The completeness of staging fashions in traditional performing art, dance movements and various performances packaged in wayang performances unconsciously related to mathematics.

According to Prabowo and Pramono (2010) stated that mathematics is the construction of human culture. In line with Hariastuti (2017) stated ethnomathematics can be studied how people understand, express and use the concepts of culture which described mathematically. Ascher (1995)supports this idea by stating that mathematics facilitates the daily life and can be beneficial to improve it. Based on the description above, the researcher wants to study about ethnomathematics in Surakarta. Traditional wayang performance in Surakarta is very interesting cultural form to be studied.

\section{Review of Literature}

Mathematics comes from the root word mathema meaning knowledge, mathanein means to think or learn. Ismail et al in Hamzah and Muhlisrarini (2014: 48) explained that mathematics is a science that discusses numbers and calculations, discusses numerical problems, regarding quantity and quantity, studying the relationship of patterns, shapes and structures, means of thinking, collections of systems, structure and tools. Johnson and Myklebust in Abdurrahman (2003: 252) explained that mathematics is a symbolic language whose practical function is to express quantitative and spatial relationships while the theoretical function is to facilitate thinking.

Mathematics has experienced very rapid development. Everyone had applied mathematics in their daily lives, especially in culture. Culture is the work of mind or reason. These works are generally related to society and the universe. Koentjaraningrat (1985: 5) explained that culture is classified into three forms, among others: a form as a complexity of ideas, ideas, values, norms, etc .; the form of culture as a complexity of human patterned activities in society; c. the form of culture as objects produced by humans. That is, the first form of culture as the complexity of ideas or values can be called adat. Second, the complex form of human activity in society can be called a social system. Third, the cultural form of human work can be called physical culture. Therefore, the form of culture can be said to be in the form of customs, social systems, and physical culture.

Ethnomatematics is one branch that connects mathematics and culture.Ambrosio (1985) assertion that ethnomatematics is a mathematical science practiced by cultural groups. This statement was refined into ethnomatematics is an art or technique of understanding, explaining, learning, overcoming, managing the social realm, and politics through processes such as counting, measuring, sorting, ordering, and deducing processes resulting from group culture (Ambrosio, 1989). Similarly, Cimen (2014) explained thatethnomatematics is practice of mathematics by cultural groups in a unique form. Ethnomatematics is a program that investigates ways in which cultural groups differ in understanding, articulating, and applying concepts and practices that can be identified as mathematical practices (Barton, 1996). 
Gerdes (1994) assertion thatethnomatematics is the study of mathematics embedded in cultural contexts. In line with Adam (2010), ethnomatematics includes activities to find or reveal in various ways to know the existence of mathematics in culture. Orey M. R. (2011)assertion that ethnomatematics is a way in which concepts are related to students' cultural and daily experiences, thereby increasing their ability to describe and deepen their understanding of mathematics. In addition, ethnomatematics can be described as a way in which people from certain cultures use mathematical ideas and concepts to deal with quantitative, relational, and spatial aspects of their lives (Borba, 1997).

\section{Research Method}

This research uses qualitative approach. It is a research resulting descriptive data and observable attitude of the subject. The research aims to obtain information about Ethnomathematics in traditional wayang performance in Surakarta, including the dressing, dancer movement, wayang instruments (gamelan) and stage plays.

Research and place time, this research conducted in several locations such as Sriwedari, The Indonesian Art Institute (ISI), State 8 Vocational High School (SMK) and State 1 Junior High School (SMP). The places chosen based on considerations that: (1) Sriwedari is a place to perform wayangorang every night, where researcher could observe wayang instruments, performance and the complicated wayang costume; (2) The Indonesian Art Institute (ISI) is the only university in Surakarta which has dance and karawitan department, so that the researcher might see artists or lecturers to interview about ethnomathematics, and also Java or non Java traditional dance related to traditional culture; (3) State 8 Vocational High School (SMK) 8 is also the only institution having dance and karawitan subject in Surakarta, where researcher may observe dance learning process for stage play; (4) State 1 Junior High School (SMP) is the most favorite school in Surakarta, where researcher could interview teachers about the material, learning process and ethnomathematics.

The subject of this research is the actors of wayang performance, artists and traditional art teachers. In this case, the researcher has considerations, those are: (1) the actors are interview because their involvement in all wayang performance; (2) artists are expert in traditional culture; and (3) teachers are figures understanding widely of the material, learning process and ethnomathematics.

The phases of the research are (1) defining and formulating problems clearly though from the width side, (2) the introduction intends to the valid theories or previous researches, (3) formulating hypothesis helps researcher's thinking framework to achieve research purposes, (4) determining research design, (5) collecting data using appropriate technique, (6) processing and serving collected information for further analysis, (7) analyzing and interpreting the processed data for further study, (8) concluding the findings based on research purposes, and (9) conducting the research report.

The data of this research was resulted from observation, interview and documentation. Sugiyono (2008) said that observation is the basic of knowledge. The observation was done by watching series of wayang performances from the training to staging. Moleong (2008)stated that interview is dialogue with particular aims. The dialogue was done by two persons, who were the interviewer and interview. Sugiyono (2008) also explained that document is a note of the past events. Document could be writings, pictures, or one's works. 
Data analysis method used in this research is (1) data reduction including noting down interview report and observation related to ethnomathematics in wayang performance, (2) data presentation in text, narrative and note form as the interview result, and (3) concluding research in a text to know ethnomathematics of wayang performance in Surakarta. Data validity was checked by data triangulation that was combining observation, interview and documentation method.

\section{Result and Discussion}

The result of ethnomathematic research in Traditional Wayang Performance in Surakarta which has been conducted in the doll-puppet from the ethnomathematical point of view is found modulo 9 conception, Solid figure, odd and even number, rectangle, and circle. The followings are the explanations.

\subsection{Modulo 9}

Modulo 9 is number operation which produces the remaining-divided number from one number to other numbers. The example is $7 \bmod 5=2$ because 7 remains 2 if it is devided by 5. In the dance show, the dancers practiced dancing before the show so that the performance became maximal. In the process of practicing, there must be counting for movement accuracy. The counting starts from 1 to 8 and it refers to 1 again after 8 .

Adam (2010) also mentions that ethnomathematics includes the activity of exploring and use several ways to know the existence of mathematics in culture. The equation of modulo 9 conception and dance practice can be seen from the model of counting. In modulo9 , number 8 after will be started by 0 then 1 . The same way is also applied in the dance practice. The difference here is in the dance practice which is mathematical number of modulo 9 and when it comes the counting of 9,0 is not pronounced. This then causes the counting repeated from 1 to 8 . Therefore the counting of dance practice applied modulo 9 .

\subsection{Solid figure}

Solid Figure constitutes a figure which has three dimensions. The example of solid figures are cone, sphere, cuboid, cube. And etc. This research finds the concept of solid figure in the doll-puppet show which is head cover of puppet. The head cover of puppet is one of parts of fashion which is used by the character of doll puppet. The use of it is to clarify the characters of the puppets. The head cover of puppet is made of grinned skin leathered by velvet and some decorations.

The shape of doll-puppet-head caps was various. Those were a)Tekes, b)Tropong, c)Pogog, d)Keton, and e)Irah-irahan. The shape of head cap was adapted with the character of puppet. The following article just explains the head cap of Tekes. This is because of the limitation of article page. The article about tekes is as follow.

Tekes usually was used by Knights such as Kelana.Tekeshead cover utilizes mathematical knowledge. It can be seen from its shape. The form of Tekes head applies semicricle solid figure. The half of circle belongs to the solid figure. According to the interview with Art teacher from State 1 Junior High School in Surakarta, Mrs. SumtiningPujowati, S.Sn, it is found that in the fashion of puppet show, the head cover uses mathematical knowledge which is semi-circle.Borba (1997) also argues that ethnomathematics can be used as a method employed by people from different cultures use the concepts and ideas of mathematics in facilitating their daily life. 
Table 1. Ethnomathematics in the head cover of puppet

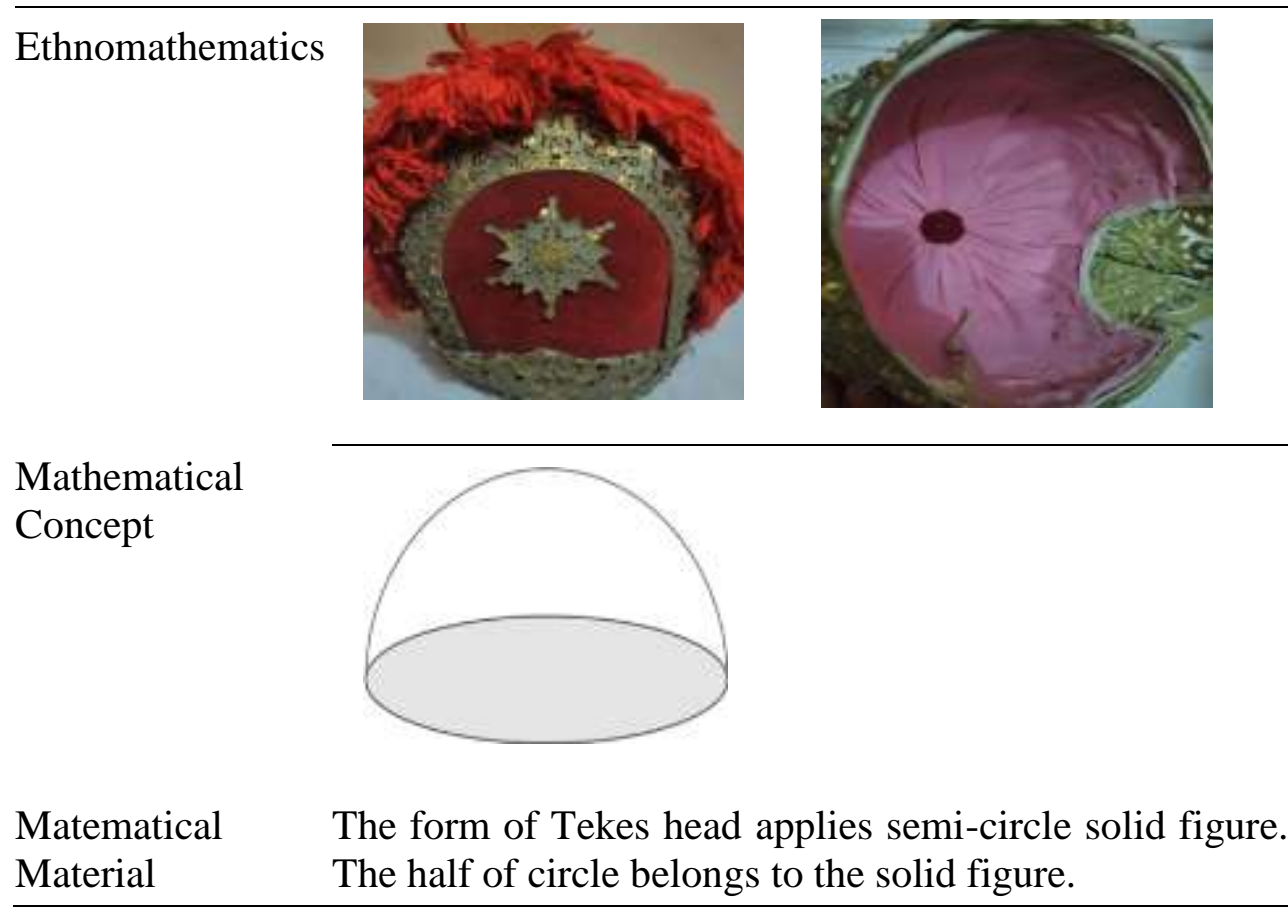

From the elaboration above, the making of head cap applies mathematical knowledge which is solid figure. To make it, a cardboard is shaped in semi-circle then is leathered by skin and velvet.

\subsection{Odd and Even Number}

The odd number is an integer which is not a multiple of two. An even number is an integer which is "evenly divisible" by two. In the show, there were some kinds of performances. Indonesian Art Institute (ISI) not only performancedjavanese dance, but also dances coming from outside java island. Some dances had specific characterisitics because the dancers must be organized. Such as plate dance which had to have odd number of dancers $(3,5,7$ people). The specific characteristics were also found in umbrella dance which had to possess even number if dancers ( $4,6,8$ people).

The odd and even number can be applied in the specific dancing as what has been explained above. Therefore, to determine the number of dancers, it requires mathematical knowledge which is odd and even number. To have numbers of dancers, it is obligatory to understand odd and even number in advance.

\subsection{Rectangle}

A rectangle is a flat building that has special characteristics, namely a) the sides facing with the same length, b) the four angles of the elbows, c) the diagonal - the diagonals are the same length and bisect the same length. This study found the concept of rectangles in wayang instruments (gamelan). On Wayang performances, the supporting tools used to make the performance even lively. 
Wayang performance, the supporting tools used are gamelan. The types of gamelan are kendhang, gender, demung, saron, peking, kenong, slenthem, kempul, gong, and others. Some of the bilah in the gamelan are rectangular. Examples of gamelan blades are rectangles, demung, saron, peking, gender, and slenthem.

Table 2. Ethnomathematics in bilah gamelan

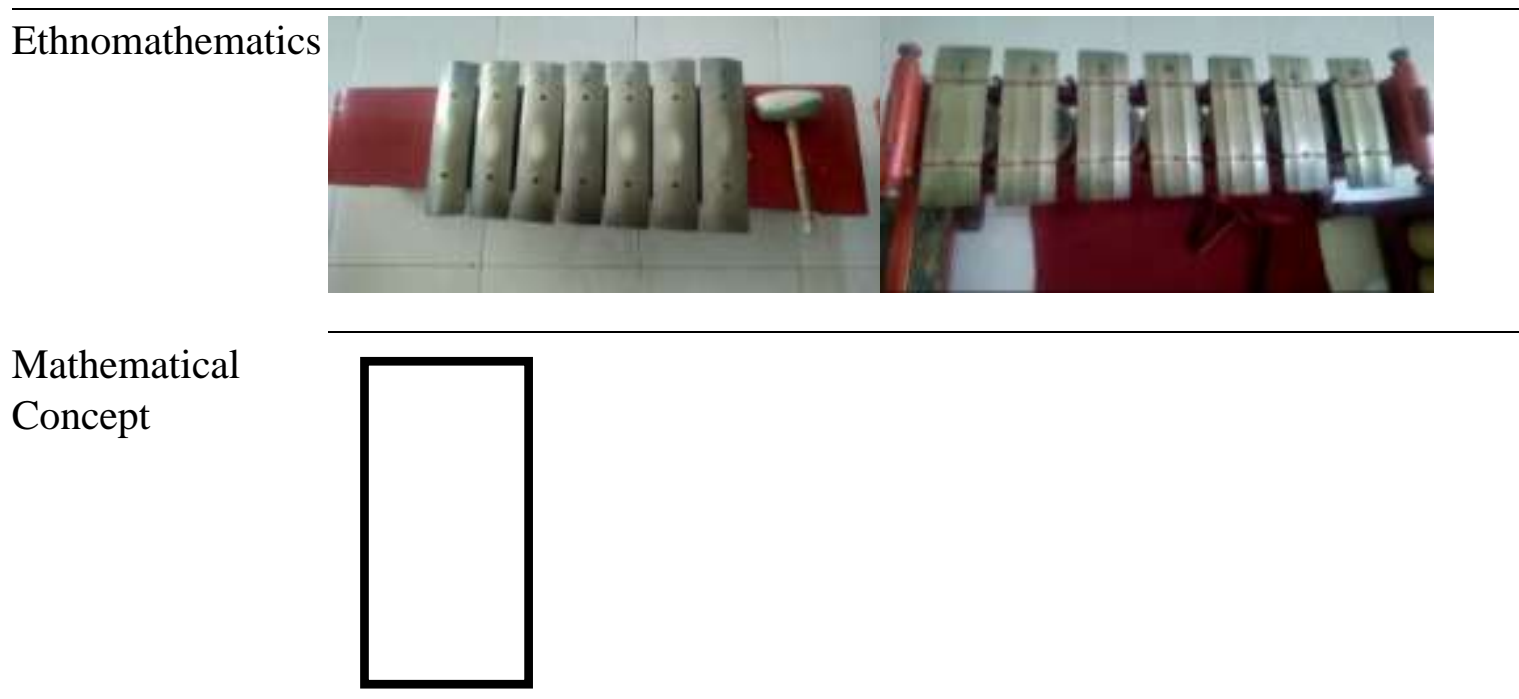

Matematical Bilah in gamelan use mathematical material namely rectangles.

Material

From the description above, the bilah in gamelan use mathematical material namely rectangles.

\subsection{Circle}

The circle is a curved line that meets both ends and all the far points are equal to a certain point. According to the type of play, the gamelan is divided into gamelan played by beating, by swiping, and played by picking. The one played by beating including balungan, gender, kenong, drum, kempul and gong. The one played by swiping the fiddle is played by picking a siter.

According to the interview with Surakarta Junior High School 1 teacher, Mr. ArdiGunawan, S.Sn, on several types of gamelan which were played looking for beaten using mathematics, namely the concept of a circular flat shape. Gamelan types that utilize the concept of flat circle building, are namely kendhang, kempul, and gong. 
Table 3. Ethnomathematics in gendhang, kempul, and gong

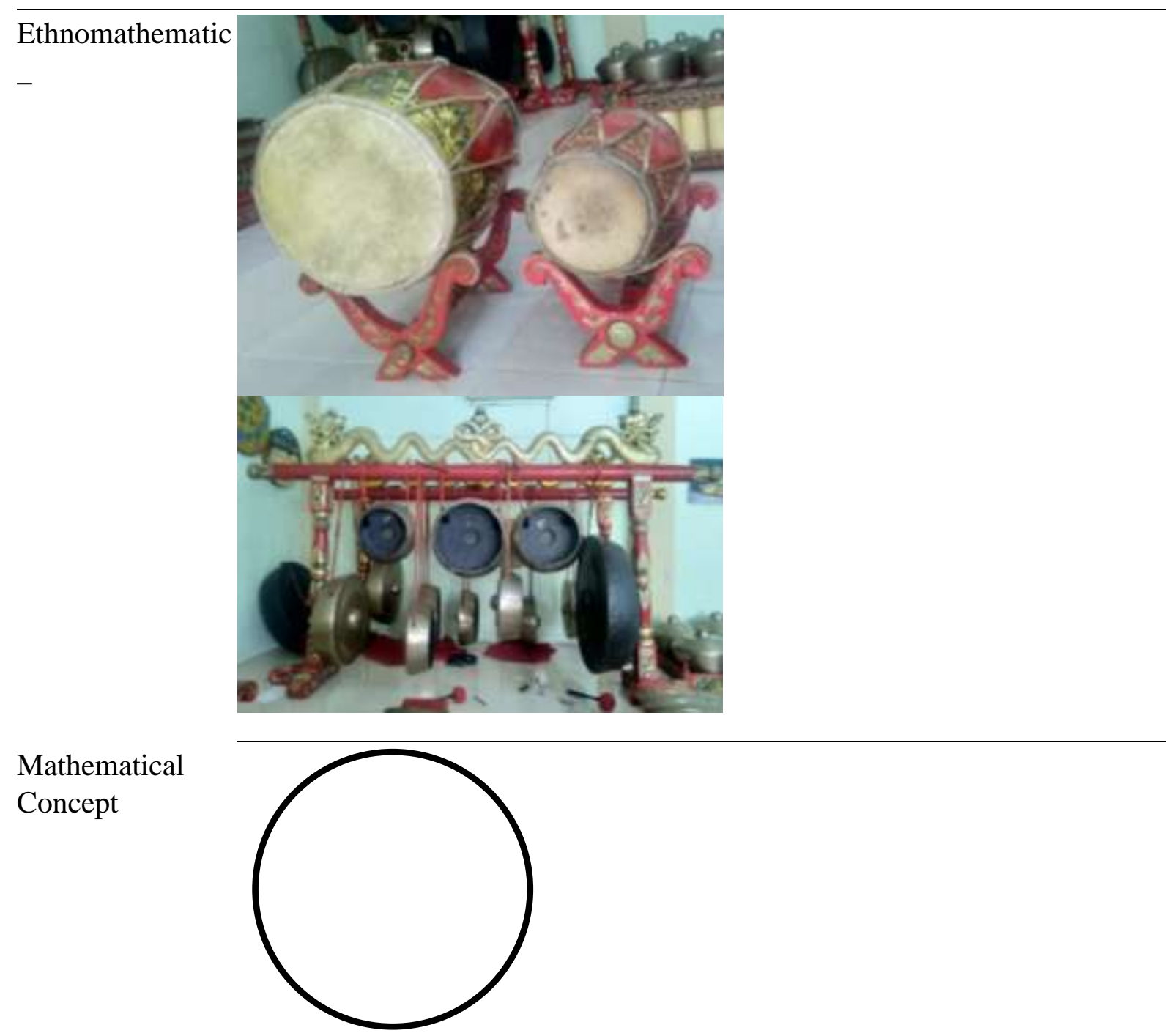

Matematical Several types of gamelan can be played by beating using the concept of a Material circular flat shape.

From the description above, several types of gamelan can be played by beating using the concept of a circular flat shape.

\section{Conclusion}

This research serves the ethnomathematic results in the art and traditional puppet show in Surakarta. Based on the datum analysis and research discussion, it can be concluded that art and traditional puppet show in Surakarta contains conceptions of mathematics which is modulo 9, solid figure, odd and even number, rectangle, and circle. The counting of dancing practice applies modulo 9 conception. The head cover of doll puppet applies solid figure. The 
number of dancers applies odd and even number conception. The bilah in gamelan use mathematical material namely rectangles. That last, several types of gamelan can be played by beating using the concept of a circular flat shape.

\section{Acknowledgment}

The author's acknowledgments goes to:

1. Mrs. SumtiningPujowati, S.Sn, and Mr. ArdiGunawan, S.Sn that already give information.

2. Principal, teachers and students of State 1 Junior High School (SMP), State 8 Vocational High School (SMK), The Indonesian Art Institute(ISI), and Sriwedari which has provided the opportunity and time to help finish in this study.

\section{References}

Abdurrahman, Mulyono. (2003). Pendidikan Bagi Anak Berkesulitan Belajar. Jakarta: Rineka Cipta.

Adam N A 2010 Mutual Interrogation: A Methodological Process in Ethnomathematical Research Procedia Social and Behavioral Science

Ambrosio U 1985 Ethnomathematics and its place in the history and pedagogy of mathematicsFor the Learning of Mathematics vol 5 chapter 1 pp 44-48

Ascher M 1995 Models and Maps from the MarshallIsland: A Case in Ethnomathematics Historia Mathematica

Barton B 1996 Ethnomathematics: Exploring cultural diversity in mathematics(Auckland: University of Auckland)

Borba M C 1997 Ethnomathematics and educationEthnomathe-matics: Challenging Eurocentrism in mathematics education ed A B Powell and M Frankeinstein (New York: State University of New York Press)

Gerdes P 1994 Reflections on mathematicsFor the Learning of Mathematics vol 14 chapter 2 pp 19-22

Hamzah, Ali dan Muhlisrarini. (2014). Perencanaan dan Strategi Pembelajaran Matematika. Jakarta: PT Raja Grafindo Persada.

Hariastuti R M2017 Permainan tebak-tebakan buah manggis: sebuah inovasi pembelajaran matematika berbasis etnomatematika Jurnal Matematika Dan Pendidikan Matematika vol 2 chapter 1 pp 25-35

Koentjaraningrat1985 Kebudayaan Mentalis dan Pembangunan(Jakarta: PT Gramedia)

Moleong L J 2008 Metodologi Penelitian Kualitatif (Bandung: Remaja Rosdakarya)

Orey M R 2011 Ethnomathematics: the cultural aspects of mathematics Revista Latinoamericana de Etnoma-tematica

Prabowo A and Pramono S 2010 Memahat Karakter Melalui Pembelajaran Matematika International Conference on Teacher Education

Sugiyono 2008 Memahami Penelitian Kualitatif (Bandung: Alfabeta)

Torres-Velasquez D and Lobo G 2004 Culturally responsive mathematics teaching and English language learners Teaching Children Mathematics 